\title{
Retraction Note: Abnormal anti-cyclone in ocean atmosphere and sports swimming strength training based on target tracking algorithm
}

\author{
Shuang Zhao ${ }^{1}$
}

Published online: 17 November 2021

(c) Saudi Society for Geosciences 2021

Retraction Note: Arabian Journal of Geosciences (2021) 14: 1898

https://doi.org/10.1007/s12517-021-08160-6

The Editor-in-Chief and the Publisher have retracted this article because the content of this article is nonsensical. The peer review process was not carried out in accordance with the Publisher's peer review policy. The author has not responded to correspondence regarding this retraction.

The original article can be found online at https://doi.org/10.1007/ s12517-021-08160-6.

Shuang Zhao

15951893665@163.com

1 Department of Physical Education, Jiangsu Maritime Institute, Nanjing 211170, China 